\title{
IMPLEMENTASI BUDAYA HANDOP DALAM MEMPERERAT TALI \\ SILAHTURAHMI DALAM KOMUNITAS SOSIAL \\ MASYARAKAT DESA PANEKASAN \\ KECAMATAN SERAWAI
}

Suparno, Veronika Yosi Andriani, Septha Suseka

STKIP Persada Khatulistiwa Sintang, Program Studi Pendidikan Pancasila dan Kewarganegaraan Email: suparnowae4@gmail.com, veronikayossi2@gmail.com.

\begin{abstract}
Abstarck
The purpose of this research is that in general, this study aims to find out the reasons why Handop culture can strengthen the relationship between the pople of Panekasan village, Serawai district. The method used is a qualitative ethnographic approach. The result in this study are the process of implementing the Handop culture which is routinely carried out every year so that it can strengthen community ties. The conclusion tn this study is that the Handop culture is a culture inherited from the ancestors of the Dayak Uud Danum tribe and can unite the community during the implementation of Handop in Panekasan village, Serawai district
\end{abstract}

Keywords: Handop, Social Communities. 


\begin{abstract}
Abstrak
Tujuan dalam penelitian adalah Secara umum penelitian ini bertujuan untuk mengetahui alasan mengapa budaya Handop dapat mempererat tali silahturami masyarakat Desa Panekasan Kecamatan serawai. Metode yang digunakan adalah pendekatan kualitatif bentuk etnografi. Hasil dalam penelitian ini yaitu proses pelaksanaan budaya Handop yang rutin dilaksanakan setiap tahunnya sehingga dapat mempererat tali silahturahmi masyarakat. Kesimpulan dalam penelitian ini adalah budaya Handop merupakan budaya yang diwariskan oleh nenek moyang suku dayak Uud Danum dan dapat menyatukan masyarakat saat pelaksanaan Handop yang ada di Desa Panekasan Kecamatan Serawai.
\end{abstract}

Kata Kunci: Handop, Komunitas Sosial 


\section{PENDAHULUN}

Indonesia adalah negara yang kaya akan suku bangsa dan budaya yang tersebar dari Sabang sampai Merauke, serta memiliki banyak budaya dan tradisi dari setiap suku bangsa. Namun dari sekian banyak suku bangsa di Indonesia ada suku bangsa yang memiliki adat istiadat yang unik. Masyarakat Indonesia adalah masyarakat yang majemuk, salah satu ciri dari kemajemukan tersebut adalah terdapat beranekaragam kebudayaan yang dilaksanakan dan di lestarikan oleh masing-masing masyarakatnya. Kegiatan kebudayaan tersebut mempunyai bentuk atau cara melestarikan kebudayaan serta maksud dan tujuan yang berbeda antara kelompok masyarakat satu dengan masyarakat lainnya hal ini di sebabkan adanya perbedaan lingkungan tempat tinggal, adat serta tradisi yang diwariskan secara turun temurun. Seperti halnya suku Dayak Kalimantan mengedepankan budaya leluhurnya sehingga kebudayaan tersebut dapat dilestarikan hingga anak cucu kelak. Masyarakat Kalimantan memiliki kebudayaan yang berbeda pada setiap lapisan masyarakatnya atau setiap sub suku nya seperti suku Dayak Uud
Danum memiliki budaya Handop yang dilakukan atau dilaksanakan pada saat orang melakukan kegiatan berladang.Suku dayak Uud Danum ini berada di Kalimantan Barat tepatnya di Kecamatan Serawai Kabupaten Sintang, namun suku Dayak Uud Danum tidak hanya berada di Serawai tetapi ada juga yang berada di Kecamatan Ambalau.

Kecamatan Serawai berada di hulu sungai Melawi jarak tempuh dari kota Sintang cukup jauh sekitar 6-7 jam menggunakan speed boat. Dayak Uud Danum memiliki arti yaitu Uud artinya “ hulu dari sebuah sungai”. Sedangkan Danum artinya “ air” atau bisa juga diartikan sebagai "sungai". Jadi secara garis besar arti Uud Danum adalah "hulu sungai" dengan demikian suku dayak Uud Danum bisa diartikan sebagai orang-orang yang tinggal di hulu sungai. Handop adalah salah satu budaya yang dimiliki suku Dayak Uud Danum yang dilaksanakan pada saat musim berladang. Budaya Handop juga dapat diartikan sebagai budaya Gotong Royong namun dalam suku Dayak Uud danum memiliki nama yang berbeda karena dalam bahasa Arok-arok atau 
bahasa suku dayak Uud Danum Gotong Royong adalah Handop.

Handop ini akan dilaksanakan pada saat musim berladang dalam budaya Handop juga ada beberapa ritual yang dilakukan maka dari itu masyarakat selalu melaksanakan budaya ini supaya selalu terjaga kebudayaan mereka yang diwariskan oleh leluhur. Budaya Handop juga dapat mempererat tali silaturahmi masyarakat karena dengan adanya budaya ini dapat mengumpulkan masyarakat untuk ikut melaksanakan budaya ini.

Kecamatan Serawai adalah Kecamatan yang rata-rata masyarakatnya adalah suku Dayak Uud Danum, bahasa yang digunakan adalah bahasa ArokArok, Arok berarti ada. Dalam hal ini budaya Handop masih sering dilaksanakan oleh masyarakat. Salah satu contoh budaya Handop adalah pada saat menebas ladang, dimana semua masyarakat dapat turut membantu pada saat pembuatan lahan untuk berladang.

Masyarakat Dayak Uud Danum meyakini budaya Handop adalah buadaya yang dapat mempererat tali silaturahmi antara saudara, keluarga maupun masyarakat lainnya, karena dengan adanya budaya ini masyarakat dapat berkumpul bersama dan dapat bersenda gurau sambil melakukan kegiatan berladang mereka. Budaya Handop tidak hanya dilaksanakan oleh para orang tua namun anak muda juga dapat melakukannya, namun budaya ini sering dilakukan oleh orang-orang yang sudah menikah dan untuk anak mudanya hanya membantu orang tua mereka.

Namun generasa saat ini banyak yang sudah tidak mau melakukan budaya Handop ini karena kebanyakan sudah tidak mau berladang lagi serta dalam masyarakat kebersamaan masyarakat sudah tidak seerat dulu. Kebanyakan masyarakat sibuk akan kegiatan dan pekerjaan mereka masing-masing sehingga kebersamaan antar masyarakat mulai luntur akibat masyarakat yang individualis. Sudah jarang masyarakat yang mau membantu sesamanya dengan ikhlas mereka hanya mau membantu sesama jika ada imbalan nya.

Hasil Pra Observasi yang peneliti temukan yang mana generasi saat ini banyak yang sudah tidak mau melakukan budaya Handop ini karena kebanyakan sudah tidak mau berladang lagi serta banyak yang sibuk dengan pekerjaan masing-masing, di Desa ini masyarakat kebanyakan bekerja sebagai penambang 
tradisional namun saat ini dalam masyarakat kebersamaan sudah tidak seerat dulu,. Pada saat ini sudah jarang masyarakat yang mau membantu sesamanya dengan ikhlas mereka hanya mau membantu sesama jika ada bayaran saja. Inilah sebabnya mengapa peneliti tertarik untuk meneliti tentang Budaya Handop yang ada di Desa Panekasan serta mengapa Peneliti mengambil judul implementasi budaya Handop dalam mempererat tali silaturahmi dalam komunitas sosial masyarakat desa panekasan kecamatan serawai, supaya dapat mengembalikan keadaan masyarakat seperti dulu melalui budaya Handop.

\section{METODE PENELITIAN}

Metodologi penelitian berasal dari kata "metode" yang artinya cara tepat untuk melakukan sesuatu dan "logos" yang artnya ilmu pengetahuan. Jadi metodologi artinya cara melakukan sesuatu dengan menggunakan pikiran secara seksama untuk mencapai suatu tujuan. (Sugiyono 2012:60). menurut (Penny dalam Narbuko dan Achmadi 2009:1) menyatakan penelitian adalah pemikiran yang sistematis mengenai berbagai jenis masalah yang pemecahannya

memerlukan pengumpulan dan penafsiran fakta-fakta. Metodologi penelitian pada dasarnya merupakan cara ilmiah untuk mendapatkan data dengan tujuan dan kegunaan tertentu, Babbie ( Mamang dan Sopiah 2010:4). Cara ilmiah memiliki karakteristik rasional, empiris, dan sistematis. Rasional berarti penelitian dilakukan dengan cara-cara masuk akal dan terjangkau penalaran atau logika manusia. Empiris berartri penelitian dilakukan berdasarkan faktafakta dilapangan yang dapat di uji oleh orang lain atau pihak lain. Kemudian sistematis berarti penelitian merupakan proses tertentu yang logis.

Metodologi penelitian merupakan suatu cara atau teknis yang dilakukan dalam proses penelitian dan upaya dalam bidang ilmu pengetahuan yang dijalankan untuk memperoleh fakta-fakta dan prinsip-prinsip dengan sabar, hatihati, dan sistematis untuk mewujudkan kebenaran. Dalam penelitian ini, peneliti menggunakan metode penelitian kualitatif deskriptif (Sugiyono, 2010:15).

Metode penelitian kualitatif sering juga disebut sebagai metode artistic yang beraliran positif. Dengan perkataan lain, metode ini merupakan metode penelitian 
yang berlandaskan pada filsafat Postpositivisme, digunakan untuk meneliti pada kondisi objek yang alamiah.

\section{HASIL PEMBAHASAN}

Analisis hasil belajar PKn siswa melalui metode Etnografi:

\section{Proses Pelaksanaan Budaya}

\section{Handop Suku Dayak Uud Danum.}

Berdasarkan hasil penelitian yang dilakukan pada saat melakukan penelitian bahwa didalam proses pelaksanaan Handop terdapat beberapa proses dan beberapa tahap didalam pelaksanaannya, pada saat Handop terdapat proses yang dimana setiap proses memiliki makna dan tujuan tertentu. Didalam proses Handop terdapat beberapa alat yang digunakan dalam pelaksanaan Handop seperti parang, batu asah ( canai), dan lain sebagainya.

Sebelum proses pelaksanaan Handop masyarakat berkumpul terlebih dahulu untuk menentukan siapa saja yang ikut dalam pelaksanaan Handop serta menentukan jadwal, setelah menentukan jadwal Handop maka akan ditentukan siapa yang akan duluan memulai Handop di ladang nya. Pada hari yang sudah ditentukan sebagai hari dimana awal pelaksanaan Handop dilakukan, sebelum berangkat ke ladang masyarakat akan sarapa di rumah masing-masing sesuai kesepakatan yang telah di tentukan.

Kemudian pada pelaksanaan Handop masyarakat akan berangkat bersama-sama ke lokasi ladang yang akan dikelola pada saat Handop tujuannya supaya tidak ada yang tersesat, sesampainya diladang si pelaksana Handop akan menghidupkan api untuk menanak air untuk membuat kopi sembari membuat kopi beberapa orang akan bertugas mengasah parang tujuannya agar parang terasa tajam dan siap digunakan untuk menebas ladang sebelum mengasah parang salah satu dari mereka akan menyembelih ayam untuk diambil darahnya dan di sirami diatas batu asah kegiatan ini tujuannya untuk memberkati batu asah agar memberikan ketajama parang dan tidak membahayakan bagi penggunanya. Setelah mengasah parang maka mereka akan minum kopi sembari bercerita dan bercanda bersama, kemudian setelah selesai minum kopi seluruh masyarakat akan memulai menebas ladang sampai pada titik yang sudah di tentukan oleh 
pemilik ladang, adapun salah satu dari mereka bertugas untuk memasak, kemudian jika sudah waktu nya istirahat makanya seluruh masyarakat akan pulang ke osah (pondok) untuk beristirahat dan makan bersama dengan hidangan yang sudah di siapkan oleh pemilik ladang, lauk yang disiapkan akan dibagi kedalam piring masingmasing sehingga semua masyarakat dapat merasakan hidangan yang di siapkan oleh pemilik ladang.

Pada saat jam menunjuk pukul satu maka masyarakat akan melanjutkan untuk menebas ladang sampai pada batas yang di tentukan pemilik ladang, saat menebas ladang masyarakat akan saling bercanda gurau antara satu dengan yang lain dengan sesekali menjaili yang lainnya sehingga kebersamaan dan kekeluargaan terjalin dengan sangat erat, masyarakat yang ikut dalam pelaksanaan Budaya Handop adalah orang tua dan anak muda serta anak muda yang sudah menikah makanya tidak heran jika suasana menjadi hangat karena candaan dan gurauan dari setiap orang yang hadir pada saat Handop.

Jika pemilik ladang mengatakan sudah cukup maka pelaksanaan handop di ladang tersebut selesai kemudian akan dilanjutkan esok hari diladang yang berbeda dan pemilik yang berbeda dengan kegiatan dan cara yang sama. Pelaksanaan Handop biasanya berlangsung cukup lama sesuai jumlah orang yang ikut kegiatan Hando, saat kegiatan Monahtik (menebas) pasti selalu ada hambatan seperti cuaca maupun dari mimpi yang dimimpikan oleh anggota Handop jika mimpi nya kurang baik maka kegiatan Handop akan di lanjutkan pada hari berikutnya dan masyarakat juga masih percaya dengan ramalan penampakan bentuk dan fase bulan cembung akhir merupakan ramalan fase bulan kurang baik untuk mengawali pembuatan ladang atau pengelolaan ladang.

Kemudian setelah Menahtik (menebas) selesai maka masyarakat akan melanjutkan ke kegiatan Muhpuk (menebang bambu) saat menebang bambo proses nya sama dengan Menahtik dari ladang satu ke ladang yang lainnya . Tujuan muhpuk (menebang bambu) supaya pada saat menebang pohon nanti tidak terganggu dengan adanya bambu karena bambu dapat menghambat pada saat penebangan pohon nantinya maka bambu akan lebih dahulu di potong atau 
ditebang. Menebang bambu ini tidak full dalam sehari pekerjaan nya karena terkadang ada yang ladang nya tidak di tumbuhi bambu maka dari itu pelaksanaan muhpuk hanya dilakukan oleh orang-orang yang merasa dilahan yang akan dijadikan ladang terdapat tumbuhan bambu saja.

Kemudian jika muhpuk sudah selesai maka masyarakat akan melanjutkan dengan Nowong ( penebangan pohon) saat Nowong maka masyarakat akan memulai Handop lagi untuk menebang pohon yang terdapat di lahan ladang mereka supaya lahan mudah untuk diolah nantinya. Biasanya pada saat Nowong masyarakat akan menggunakan alat seperti parang, kapak dan sinso supaya memudahkan mereka pada saat menebang pohon yang besar maupun yang kecil, jika menggunakan sinso maka bagi masyarakat yang meiliki sinso akan diwajibkan untuk dibawa supaya proses menebang cepat selesai. Untuk kegiatan Nowong ini biasanya dilakukan oleh kaum laki-laki karena sangat berbahaya makanya kaum perempuan tidak diwajibkan ikut agar sesuatu yang tidak diinginkan tidak terjadi. Jika terjadi sesuai yang tidak diinginkan pada saat menebang ladang atau misalnya luka maka orang yang punya ladang akan menanggung biaya pengobatan dan Nyahkik nyiro atau Nyengkelan orang yang terluka. Jika luka mengenai bagian kepala maka akan dikenakan Ulun atau denda adat sesuai aturan adat setempat karena dipercaya masyarakat bagian kepala sangat fatal makanya jika luka mengenai kepala akan dikenakan denda adat yaitu Ulun dua dikenakan biaya Rp. 1.000.000 karena satu Ulun dikenakan biaya Rp. 500.000, dan akan di sengkelan dengan Babi dan ayam.

Setelah Nowong (menebang pohon) maka masyarakat akan melanjutkan ke tahap Ngihang Dowak (menjemur ladang) penjemuran dilakukan supaya pohon dan bambu yang sudah ditebang bisa layu secepatnya agar mudah untuk dibakar pada saat pembakaran ladang. Ngihang dowak biasanya disesuaikan dengan cuaca jika cuaca panas maka tidak memakan waktu terlalu lama tetapi jika cuaca hujan maka akan memakan waktu yang cukup lama bahkan sampai berbulan-bulan untuk sampai ke proses selanjutnya yaitu bakar ladang. Saat Ngihang Dowak masyarakat tidak mengadakan Handop untuk beberapa 
waktu karena tidak membutuhkan tenaga dalam proses ini sehingga masyarakat dapat kembali bekerja ke pekerjaan sehari-hari mereka untuk mencari nafkah, dan menyiapkan persediaan bahan makanan yang akan di gunakan pada saat Handop selanjutnya nanti

Jika Ngihang Dowak sudah selesai maka masyarakat akan Handop untuk membakar ladang tujuannya supaya ada yang menjaga api agar tidak keluar ke area lain dan tidak terjadi kebakaran hutan atau di sebut Sasau dalam bahasa Dayak Uud Danum. Api dijaga dengan ketat supaya tidak menjalar ke tempat lain karena jika api menjalar ke kebun orang maka akan di kenakan Ulun atau denda adat yang mana denda adat akan di tentukan sesuai seberapa luas lahan yang terbakar. Pembakaran hutan dilakukan dengan cara Handop atau bergotong royong saling membantu satu sama lainnya.

Karena pembakaran sudah selesai maka dilanjutkan dengan Nuhkan (menugal ladang) menugal ladang ini akan diawali dengan upacara adat yang mana dengan membunuh ayam dan diambil darahnya untuk Nyengkelan atau memberkati lahan maupun padi yang akan ditanam tujuan nya untuk memberkati tanah yang sudah dibakar supaya dapat menumbuhkan tanaman dengan baik dan supaya padi dapat tumbuh subur yang mana dapat mengahasilkan hasil yang lumayan banyak. Pemberkatan tanah dilakukan oleh orang yang sudah terbiasa dan faham dengan mantra atau doa nya. Menuggal ini semua porsenya sama yaitu dengan Handop atau gotong royong, alat yang digunakan seperti kayu yang diruncingkan pada salah satunya yang diebut tugal atau untuk melobangi tanah yang akan ditanami padi oleh masyarakat dan takin atau alat yang terbuat dari rotan yang dijadikan sebagai tempat untuk wadah penyimpanan padi pada saat pelaksanaan nugal. Pada saat nugal maka padi yang akan ditanami sudah disiapkan oleh pemilik ladang yang mana bibit padinya terdiri dari beberapa jenis sesuai dengan yang sudah ditentukan oleh pemilik ladang, jika penanaman jenis padi pertama maka akan dilanjutkan dengan penanaman padi selanjutnya dan hingga seterusnya.

Lahan yang akan ditanami dibaut skat atau pembatas supaya tau dimana batas jenis padi yang ditanami. Kaum bapak-bapak bertugas untuk menugal sedangkan ibu-ibu bertugas menabur 
bibit padi kedalam lubang tugal yang sudah di tugal kaum bapak-bapak dengan diselingi canda tawa disini bagi yang menggunakan tanggui maka harus menggunakan tanggui yang bahan dasarnya dari bambu jika tidak dari bahan bambu maka tidak diperbolehkan karena patang bagi masyarakat Dayak Uud Danum menggunakan tanggui yang dari bahan lain untuk di pakai diladang. Uniknya disini jika sudah selesai menugal salah satu ladang maka masyarakat akan saling melumuri teman nya dengan arang yang terdapat pada kayu bekas pembakaran sehingga akan menimbulkan gelak tawa karena mendapati wajah mereka hitam akibat arang dan kegiatan ini selalu dilaksanakan karena dipercaya masyarakat jika tidak saling melumuri dengan arang maka nugal tidak akan sah marena pulang dengan muka hitam akibat arang merupakan ciri khas menuggal ladang.

\section{Kemudian Handop akan} dilanjutkan pada saat merumput atau mencabut rumput diladang, namun terkadang ada masyarakat yang menggunakan cara instan yaitu dengan menyemprot rumput dengan racun rondap atau racun rumput lainnya supaya rumputnya mati maksimal, dalam kegiatan ini masyarakat memerlukan tabung semprot rumput, racun rondap dan air. Masyarakat akan bergotong royong menyemprot rumput yang tumbuh diladang mereka tujuannya supaya rumput tidak menghambat pertumbuhan padi yang sudah dirawat dari awal hingga menghasilkan hasil yang maksimal. Setelah merumput masyarakat masyarakat akan melakukan ritual pemberkatan padi yang sedang hamil atau padi yang sedang membungkus bunganya dengan cara memberi makan berupa sesajen yang di letakan ditengah ladang.

Sesudah merumput masyarakat menunggu hingga padi berbuah, jika padi sudah berbuah maka masyarakat akan memetik padi ketan yang mana digunakan untuk membuat makanan khas masyarakat Dayak yang ada di Kalimantan Barat yaitu Emping atau dalam Bahasa Dayak Uud Danum yaitu Itak. Kemudian setelah itu masyarakat akan memanen padi yang sudah duluan matang atau siap di panen untuk dijadikan Beras Baru gunanya supaya kita dapat merasakan beras baru sembari menunggu semuanya matang sempurna. 
Setelah semua padi di anggap siap untuk di panen (Ngohtom) maka masyarakat akan melaksanakan Handop untuk memanen padi yang sudah matang yang ada diladang mereka, masyarakat akan saling membantu dan saling menolong supaya proses memanen cepat selesai. Pada saat memanen masyarakat memerlukan takin atau bakul tambok tempat untuk meletakkan padi yang terbuat dari rotan, pisau panen, memerlukan Cuhkat atau bakul tambok tempat padi yang cukup besar dan tinggi. Masyarakat akan memanen padi dengan cara tradisional atau dengan cara lama, setelah bakul tambok dirasa sudah penuh maka masyarakat akan langsung meletakan padi di atas tikar supaya dapat dijemur dibawah matahari setelah dijemur masyarakat akan memisahkan padi dari tangkai nya dengan cara tradisional jaga supaya padi dapat diolah menjadi beras nantinya. Setelah panen selesai masyarakat akan melaksanakan kegiatan adat setempat yaitu syukuran panen yang mana kegiatan ini dilaksanakan supaya masyarakat dapat bersyukur dengan hasil panen yang mereka dapatkan diladang mereka masing-masing. Kegiatan ini masyarakat akan membunuh ayam dan babi untuk dijadikan hidangan untuk seluruh masyarakat di yang ada di Desa tersebut, kegiatan ini masyarakat juga dapat bersenang-senang dengan di selingi meminum minuman khas suku dayak yaiut Tuak atau susu Kalimantan.

\section{Budaya Handop dalam} Mempererat Tali Silahturahmi Masyarakat dalam Kegiatan Handop Suku Dayak Uud Danum.

Penelitian tentang kebersamaan masyarakat yang terdapat didalam Budaya Handop melalui cara obsevasi dan dokumentasi, dari hasil observasi dan dokumentasi yang dilakukan didalam penelitian ada beberapa nilai yang terdapat didalam Budaya Handop. Budaya Handop merupakan budaya yang di miliki oleh suku dayak Uud Danum yang berada di Kecamatan Serawai dan Kecamatan Ambalau, biasanya budaya ini selalu dilaksanakan setiap tahun nya oleh masyarakat karena merupakan sebuah tradisi yang diturunkan dari nenek moyang suku dayak Uud Danum. Melalui kegiatan ini juga dapat mempersatukan seluruh masyarakat Desa karena kegiatan ini dilaksanakan oleh masyarakat lebih dari satu orang. Tujuan Budaya Handop ini yaitu saling membantu satu sama lain 
dalam kegiatan berladang, serta untuk menyatukan masyarakat yang ada di Desa melalui kegiatan ini, selain itu juga dapat melestarikan Kebudayaan Masyarakat setempat.

Masyarakat akan mengikuti kegiatan ini dengan senang hati selain merupakan sebuah tradisi kegiatan ini juga dapat membantu masyarakat dalam mengelola lahan untuk dijadikan ladang. Saat pelaksanaan Handop masyarakat akan berangkat pagi hari dan pulang pada sore hari, saat Handop masyarakat akan bekerja dengan di selingi senda gurau yang mana dapat membuat suasana menjadi asyik bahkan terkadang ada yang saling mengganggu satu sama lain sehingga mengundang gelak tawa. Selain itu masyarakat juga dapat makan bersama saat istirahat siang serta dapat berbagi makanan dengan yang lainnya.

\section{Faktor Pendukung dan Faktor}

\section{Penghambat Budaya Handop} dalam Mempererat Tali Silahturahmi dalam Kegiatan

\section{Handop}

Selalu berkaitan erat dengan
kebersamaan yang mana dapat
menyatukan dan mempererat tali

persaudaraan satu dengan yang lain, bersamaan tidak memandang suku, ras, agama maupun asal seseorang. Kebersamaan terjalin begitu saja karena masyarakat saling membutuhkan satu dengan yang lainnya sebab manusia tidak bisa hidup tanpa manusia lainnya.

Adapun faktor pendukung dalam budaya Handop yaitu karena semua masyarakat yang ikut kegiatan handop memiliki tujuan yang sama dan saling membantu satu sama lain dalam kegiatan berladang maupun kegiatan yang lainnya. Masyarakat di Desa Panekasan memang rasa kebersamaanya sudah tidak seperti pada zaman dulu namun dengan adanya kegiatan ini dapat menyatukan masyarakat yang biasanya sibuk dengan pekerjaan masing-masing namun dapat berkumpul bersama dalam kegiatan Handop yang di laksanakan.

Faktor penghambat dalam budaya Handop yaitu masyarakat yang smasa bodoh dengan kegiatan ini dan tidak ingin berpartisipasi sehingga kurang memahami arti dan makna Handop itu sendiri. Serta faktor penghambat dari segi cuaca yang mana cuaca selalu berubah-ubah makanya dapat menghambat kegiatan Handop yang akan dilaksanakan oleh masyarakat yang 
berladang, ada juga penghambat dari mimpi buruk yang di alami oleh anggota Handop maka kegiatan Handop akan akan ditunda dalam waktu sehari serta dari fenomena fase bulan juga dapat menjadi penghambat kegiatan Handop. jika masyarakat sakit atau terluka juga dapat menjadi penghalang pelaksanaan Handop.

\section{KESIMPULAN}

1. Berdasarkan hasil penelitian yang dilakukan analisis mengenai Budaya Handop suku Dayak Uud Danum di Desa Panekasan Kecamatan Serawai Kabupaten Sintang. Bahwa Budaya Handop merupakan budaya yang masih sering dilaksanakan oleh masyarakat dayak Uud Danum karena merupakan sebuah budaya yang turun temurun dari jaman nenek moyang sampai generasi saat ini. Budaya Handop ini dilaksanakan setiap tahun dalam kegiatan berladang karena handop hanya bisa dilaksanakan pada saat berladang. Pelaksanaan Handop ini selalu diawali dengan pemberkatan secara adat suku Dayak Uud Danum yang dipercaya dapat melindungi proses pelaksanaan Handop dan memberkati lahan supaya baik digunakan serta subur untuk ditanami padi.

2. kebersamaan masyarakat yang terdapat didalam Budaya Handop melalui cara obsevasi dan dokumentasi, dari hasil observasi dan dokumentasi yang dilakukan didalam penelitian ada beberapa nilai yang terdapat didalam Budaya Handop. Budaya Handop merupakan budaya yang di miliki oleh suku dayak Uud Danum yang berada di Kecamatan Serawai dan Kecamatan Ambalau, biasanya budaya ini selalu dilaksanakan setiap tahun nya oleh masyarakat karena merupakan sebuah tradisi yang diturun kan dari nenek moyang suku dayak Uud Danum. Melalui kegiatan ini juga dapat mempersatukan seluruh masyarakat Desa karena kegiatan ini dilaksanakan oleh masyarakat lebih dari satu orang. Masyarakat akan mengikuti kegiatan ini dengan senang hati selain merupakan sebuah tradisi kegiatan ini juga dapat membantu masyarakat dalam mengelola lahan untuk dijadikan ladang.

3. Adapun faktor yang dapat menyatukan masyarakat yaitu:

a. Gotong Royong antar masyarakat 
b. Saling menghargai satu sama lain

c. Karena memiliki tujuan yang sama

d. Bekerja sama

e. Ingin menciptakan kesejahteraan bagi lingkungan

f. Keinginan untuk mencapai keamanan dan kebersihan di lingkungan tempat tinggal.

\section{DAFTAR PUSTAKA}

Afifudin, dan Beni Ahmad Saebani. 2012. Metodologi Penelitian Kualitatif. Bandung: CV. Pustaka Stia.

Bertens.2011.Etika.Jakarta:Kompas

Gramedia

Budiyono,Kabul.2012.Pendidikan

Pancasila Untuk Perguruan

Tinggi.Bandung:Alfabeta.

Darmadi, Hamid. 2009.Dasar Konsep

Pendidikan Moral. Bandung:

Alfabeta.

Deby Pebriyanti. 2017. Gotong Royong

Dalam Membangun Tongkonan

Di Desa Gandang Batu

Kecamatan Gandang Batu

Silanan Tana Toraja. Toraja:

Universitas Hasanuddin.
Endraswara, Suwardi. 2012. Metodologi Penelitian Kebudayaan. Yogyakarta: Gadjah Mada University Press.

Ernia Hariyani. 2019. Tingkat Perubahan Sikap Masyarakat Terhadap Budaya Gotong Royong Di Kampung Sawit Permai Kecamatan Dayun Kabupaten Riau. Riau: UIN SUSKA Riau.

Furchan. 2011. Pengantar Penelitian Dalam Pendidikan. Yogyakarta: Pustaka Belajar

Herskovits. 2013. Teori-teori kebudayaan. Bandung: Pustaka Setia

Humanika. (2016). Pergeseran NilaiNilai Budaya Pada Suku Bonai Sebagai Civic CultureDi KecamatanBonai Darussalam Kabupaten Rokan Hulu Provinsi Riau Vol.23. No.1

Ki Hajar Dewantara.2013. teori-teori kebudayaan. Bandung: Pustaka Setia

Koentjaraningrat.2015.Kebudayaan, Mentalitas Dan Pembangunan. Jakarta: Gramedia Pustaka Utama, Hal 9. 
Moeleong, Lexy. 2014. Metode

Penelitian Kualitatif. Bandung:

PT. Remaja Rosdakarya.

Mulyana, Deddy. 2013. Metodologi

Penelitian Kualitatif. Bandung:

PT.Remaja Rosdakarya.

Nasuiton. 1998 Metode Penelitian

kuantitatif kualitatif dan $R \& D$.

Bandung: Alfabeta, Hal 223

Narbuko,Choild dan Abu

Achmadi.2012. metodologi

penelitian. Jakarta: Bumi Aksa.

Nawawi,H. 2012. “ Metode Penelitian

Bidang Sosial”. Yogyakarta:

Gadjah Mada University Press

Nazir, Moh. 2009. Metode Penelitian.

Bandung: Ghalia Indonesia

Nurul Wahyu Lestari. 2015. Peran

Kepala Desa Dalam

Meningkatkan Kearifan Gotong

Royong Melalui Kebun Desa Di

Desa Mojosimo Kecamatan

Gajah Kabupaten Demak.

Semarang: Universitas Negeri

Semarang.

Paul Sudiyono. 2017. Pendidikan

Kewarganegaraan Di

Perguruan Tinggi. Yogyakarta:

Tema Publishing.
Samaun Maujud. 2015. Kepulauan

Maluku Utara: Universitas

Negeri Gorontalo.

Sugiyono. 2013. Metode Penelitian Pendidikan. Bandung:alfabeta . 2011. Metode Penelitian kuantitatif kualitatif dan $R \& D$. Bandung: Alfabeta.

. 2016. Metode Penelitian Kuantitatif, Kualitatif Dan $R \&$ $D$. Bandung: Alfabeta.

Sukardi.2017. Metodologi Penelitian Pendidikan Kompetensi Dan Praktiknya. Jakarta: PT Bumi Aksara.

Sulasman dan setia, G. 2013. TeoriTeori Kebudayaan. Bandung: CV Pustaka Setia.

Tamuji, Dkk.2011.ilmu alamiah dasar,ilmu sosial dasar, ilmu budaya dasar. Surabaya: IAIN Sunan Ampel Pres, hal 151

Tohirin. 2016."Metode Penelitian Kualitatif Dalam Pendidikan Dan Bibingan Konseling”. Jakarta: PT. Raja grafindo Persada. 